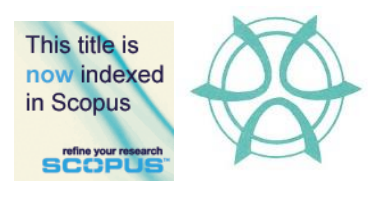

PLANNING MALAYSIA:

Journal of the Malaysian Institute of Planners

VOLUME 17 ISSUE 2 (2019), Page 50 - 61

\title{
THE TRAFFIC VOLUME AND LEVEL OF SERVICE (LOS) OF UNIVERSITI PUTRA MALAYSIA (UPM) SERDANG CAMPUS MAIN ACCESS
}

\author{
Zakiah Ponrahono ${ }^{1}$, Noorain Mohd Isa ${ }^{2}$, Ahmad Zaharin Aris ${ }^{3}, \&$ Rosta Harun ${ }^{4}$ \\ ${ }^{1,2,3,4}$ Faculty of Environmental Studies \\ UNIVERSITI PUTRA MALAYSIA
}

\begin{abstract}
The inbound and outbound traffic flow characteristic of a campus is an important physical component of overall university setting. The traffic circulation generated may create indirect effects on the environment such as, disturbance to lecturetime when traffic congestion occurs during peak-hours, loss of natural environment and greenery, degradation of the visual environment by improper or illegal parking, air pollution from motorized vehicles either moving or in idle mode due to traffic congestion, noise pollution, energy consumption, land use arrangement and health effects on the community of Universiti Putra Malaysia (UPM) Serdang. A traffic volume and Level of Service (LOS) study is required to facilitate better accessibility and improves the road capacity within the campus area. The purpose of this paper is to highlight the traffic volume and Level of Service of the main access the UPM Serdang campus. A traffic survey was conducted over three (3) weekdays during an active semester to understand the traffic flow pattern. The findings on traffic flow during peak hours are highlighted. The conclusions of on-campus traffic flow patterns are also drawn.
\end{abstract}

Keywords: campus traffic, inbound-outbound traffic flow, motorized vehicle 
PLANNING MALAYSIA

Journal of the Malaysia Institute of Planners (2019)

\section{INTRODUCTION}

The high concentration of people and traffic movement in university campus is typically due to the growth of the campus population and the university's physical development (Singh \& Goyal, 2015). UPM Serdang, as one of the leading higher learning institution in Malaysia has unique transportation needs and a comprehensive transportation plan to achieve greater sustainable campus mobility. The number of vehicles that have travelled across the campus, and consequently, their impact on the environment can be related to several determining factors (Norzalwi \& Ismail, 2011). These factors include (1) existing road infrastructure capacity; (2) quality of transportation services and facilities provisions on-campus (3) geographical setting of campus living and motor vehicle use; and, (4) low participation of sustainable transportation programs such as bus services (Abdul Azeez, 2011). Hence, a study on road capacity is necessary as the improvement of road services is important to fulfil the travel needs and reducing the impact of vehicle use to the environment setting of campuses (Abd-Razak, Mustafa, Che-Ani, Abdullah, \& Mohd-Nor, 2011; Azzali \& Abdel Sabour, 2018).

In addition, the existing transportation service system of a university may also create indirect effects on the environment such as, disturbance to lecturetime when traffic congestion occurs during peak-hours, loss of natural environment and greenery, degradation of the visual environment by improper or illegal parking, air pollution from motorized vehicles either moving or in idle mode due to traffic congestion, noise pollution, energy consumption, land use arrangement and health effects on the campus community (Lundberg \& Weber, 2014; Soria-Lara, Marquet, \& Miralles-Guasch, 2017).

Improper traffic control and management lead to the traffic congestion at the main access of the campus, as well as illegal parking at busy locations, which in turn are contributing factors to accidents and loss of road capacity as well as increase of air pollutions within the university campus (Dontu, Maftei, Barsanescu, Sachelarie, \& Budeanu, 2016). Furthermore, the phenomenon of increased vehicle travel induced by new parking spaces (added vehicle-storing capacity) is similar to the phenomenon of increased vehicle travel induced by new roads (added vehicle-carrying) capacity (Aoun, Abou-Zeid, Kaysi, \& Myntti, 2013).

A proper study on transportation planning is required to provide better accessibility and improves mobility within the campus area (Curtis \& Scheurer, 2010). Besides this, critical planning towards a sustainable and green transportation orientation campus should be on the forefront of each university administrator's blueprint (Gopikrishna \& Shanmugapriyan, 2015). This paper addresses the existing conditions of traffic flow in the Universiti Putra Malaysia Serdang campus. A traffic survey was conducted to understand the pattern of inbound and outbound of on-campus traffic flow. Findings on the existing 
Zakiah Ponrahono, Noorain Mohd Isa, Ahmad Zaharin Aris, \& Rosta Harun

The Traffic Volume and Level of Service (LOS) of Universiti Putra Malaysia Serdang Campus Main Access

conditions of traffic flow and level of service of the main access capacity derived from the survey are highlighted in this paper. The conclusions of on-campus traffic flow pattern are also drawn.

\section{MATERIALS AND METHODS}

\section{General Characteristics of the UPM Serdang campus}

Universiti Putra Malaysia (UPM) Serdang is located in Serdang, Selangor. The total number of current students in the year 2018 was 29,319 including postgraduate and undergraduate students. The main campus of Serdang covers an area of 1,200 hectares consisting of tropical greenery that situated approximately 45 kilometres $(\mathrm{km})$ from Kuala Lumpur International Airport (KLIA). It serves disciplines related to agriculture, medicine and health, architecture and design, environment and engineering and others, all housed within 16 faculties, 10 institutes, 1 school and 1 academic building. The study area includes the four (4) major entry points and the main collector road at Persiaran Universiti 1 leading to the core administration and academic area (Figure 1).

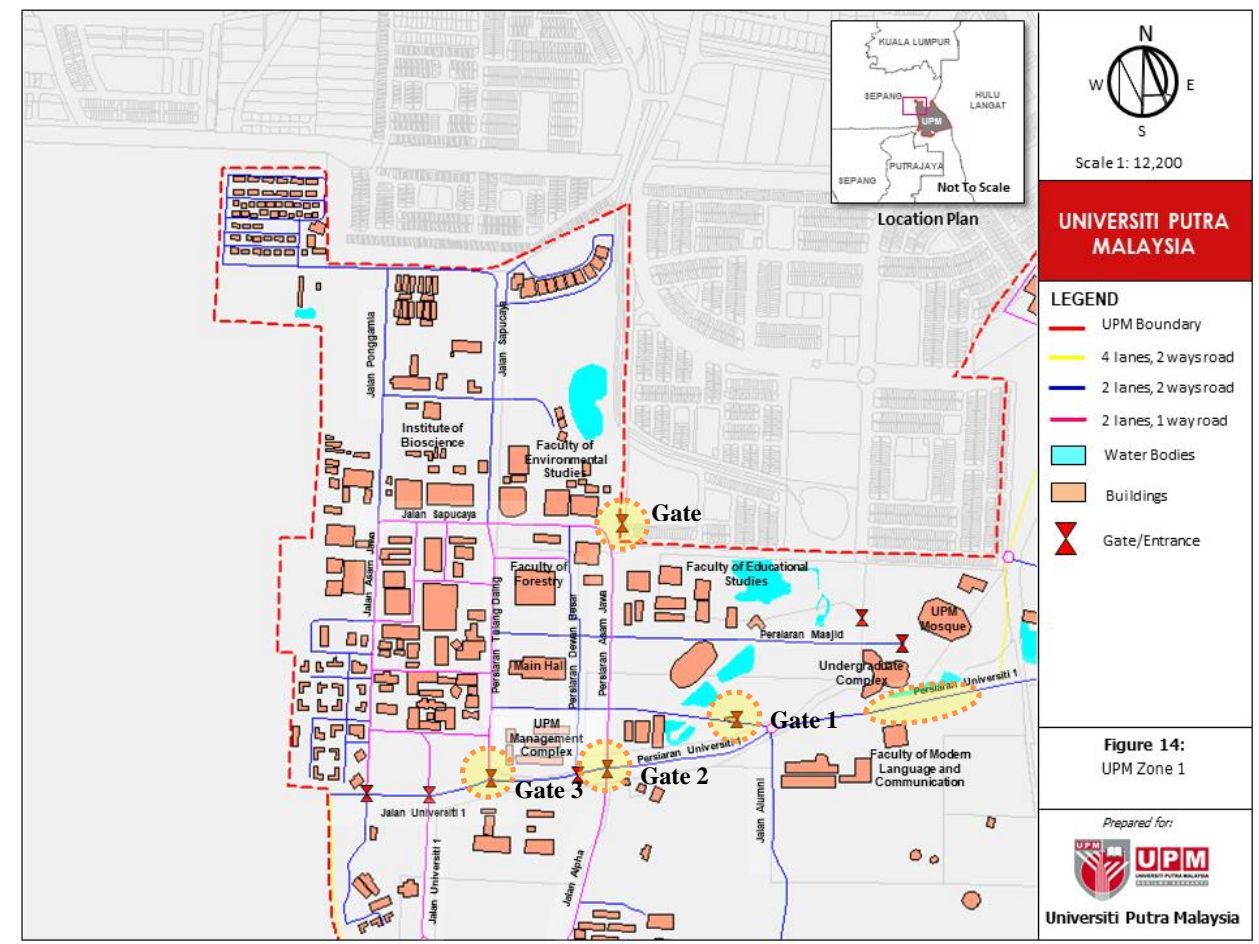

Figure 1 Universiti Putra Malaysia Serdang campus 
PLANNING MALAYSIA

Journal of the Malaysia Institute of Planners (2019)

\section{Traffic Counting and Survey}

Enumerators were located at the strategic locations identified including entrances, junctions, non-signalised intersections and significant points of potential traffic conflicts to conduct three (3) days of traffic counting during the peak hours of morning, noon and afternoon of during an active semester.

\section{Passenger Car Unit}

The urban standard of Passenger Car Unit metric was used to assess the traffic flow of the UPM Serdang campus. The value of PCU Equivalent for Urban roads is taken as: 1.0 for car/axi (4-wheelers), 0.75 for motorcycle (2-wheelers), 3.0 for bus/lorry and 0.2 for bicycle.

\section{Level of Service}

A standard Level of Service (LOS) from the Public Works Department of Malaysia is referred to assess the LOS of road service in UPM main campus, as shown in the Table 1.

Table 1 Level of service by volume/capacity ratio

\begin{tabular}{ccc}
\hline Volume/Capacity Ratio & Traffic Flow & Level of Service \\
\hline $0.0-0.2$ & Free flow & $\mathrm{A}$ \\
$0.2-0.4$ & Free flow but close to stable flow & $\mathrm{B}$ \\
$0.4-0.6$ & Stable flow & $\mathrm{C}$ \\
$0.6-0.8$ & Stable flow but close to congested & $\mathrm{D}$ \\
$0.8-1.0$ & Congested & $\mathrm{E}$ \\
More than 1.0 & Very congested & $\mathrm{F}$ \\
\hline & \multicolumn{2}{c}{ Source: Public Works Department Malaysia (1986) }
\end{tabular}

\section{RESULTS AND DISCUSSION}

\section{Traffic Volume}

Table 1, 2, 3, 4, and 5 shows the results from observed traffic volume by hours at five (5) main accesses of the UPM Serdang campus during weekdays of an active semester. Four types of transportation modes (car, motorcycle, bus and bicycle) are identified passing through the main road and entry points to the campus.

The hourly variation of traffic volume (Table 1) at Gate 1 Pintu Anjung Putra indicate that the maximum number of vehicles entering the UPM Serdang campus via this entrance was 944, between the hours of 7.00am-9.00am (Thursday), and the maximum number of vehicles leaving the campus via Gate 1 was 1,045 , between the hours $4.00 \mathrm{pm}-6.00 \mathrm{pm}$ (Wednesday). 
Zakiah Ponrahono, Noorain Mohd Isa, Ahmad Zaharin Aris, \& Rosta Harun

The Traffic Volume and Level of Service (LOS) of Universiti Putra Malaysia Serdang Campus Main Access

Table 1 Hourly Traffic Volume at Gate 1 Pintu Anjung Putra

\begin{tabular}{|l|c|c|c|c|c|c|}
\hline Count Hour & \multicolumn{2}{|c|}{ Wednesday } & \multicolumn{2}{c|}{ Thursday } & \multicolumn{2}{c|}{ Friday } \\
\hline Direction & In & Out & In & Out & In & Out \\
\hline $7.00 \mathrm{am}-9.00 \mathrm{am}$ & 903 & 478 & 944 & 433 & 501 & 340 \\
\hline $12.00 \mathrm{pm}-2.00 \mathrm{pm}$ & 637 & 819 & 597 & 635 & 220 & 389 \\
\hline $4.00 \mathrm{pm}-6.00 \mathrm{pm}$ & 528 & 1045 & 339 & 723 & 312 & 523 \\
\hline TOTAL & 2068 & 2342 & 1880 & 1791 & 1033 & 1252 \\
\hline
\end{tabular}

At Gate 2 (Table 2), the maximum number of vehicles observed leaving the campus via this entrance is 1,397 at $4.00 \mathrm{pm}-6.00 \mathrm{pm}$ (Wednesday).

Table 2 Hourly traffic volume at Gate 2 Pintu Asam Jawa

\begin{tabular}{|l|c|c|c|}
\hline Count Hour & Wednesday & Thursday & Friday \\
\hline Direction & Out & Out & Out \\
\hline $7.00 \mathrm{am}-9.00 \mathrm{am}$ & 880 & 1169 & 1058 \\
\hline $12.00 \mathrm{pm}-2.00 \mathrm{pm}$ & 1065 & 1113 & 1213 \\
\hline $4.00 \mathrm{pm}-6.00 \mathrm{pm}$ & 1397 & 1005 & 1395 \\
\hline TOTAL & 3342 & 3287 & 3666 \\
\hline
\end{tabular}

Gate 3, another inbound entrance of the campus, shows the maximum number of vehicles entering the campus via this entrance is 1,136 at $7.00 \mathrm{am}-$ 9.00am on Thursday (Table 3).

Table 3 Hourly traffic volume at Gate 3 Pintu CIMB

\begin{tabular}{|l|l|l|l|}
\hline Count Hour & Wednesday & Thursday & Friday \\
\hline Direction & In & In & In \\
\hline $7.00 \mathrm{am}-9.00 \mathrm{am}$ & 1079 & 1136 & 1132 \\
\hline $12.00 \mathrm{pm}-2.00 \mathrm{pm}$ & 892 & 292 & 817 \\
\hline $4.00 \mathrm{pm}-6.00 \mathrm{pm}$ & 770 & 562 & 901 \\
\hline TOTAL & 2741 & 1990 & 2850 \\
\hline
\end{tabular}

Meanwhile, the volume observed at Gate 9 (Table 4) shows the maximum number of vehicles entering the campus via this entrance was 1,320 at 7.00am-9.00am on Wednesday, whereas a maximum of 1298 vehicles leftthe campus at 4.00pm-6.00pm on Friday.

Table 4 Hourly traffic volume at Gate 9 Pintu Tasik Serdang

\begin{tabular}{|l|l|l|l|l|l|l|}
\hline Count Hour & \multicolumn{2}{|l|}{ Wednesday } & \multicolumn{2}{l|}{ Thursday } & Friday \\
\hline Direction & In & Out & In & Out & In & Out \\
\hline $7.00 \mathrm{am}-9.00 \mathrm{am}$ & 1320 & 674 & 1062 & 493 & 1005 & 752 \\
\hline $12.00 \mathrm{pm}-2.00 \mathrm{pm}$ & 827 & 810 & 664 & 1216 & 822 & 772 \\
\hline $4.00 \mathrm{pm}-6.00 \mathrm{pm}$ & 556 & 595 & 269 & 555 & 697 & 1298 \\
\hline TOTAL & 2703 & 2079 & 1995 & 2264 & 2524 & 2822 \\
\hline
\end{tabular}


Table 5 illustrates that a maximum of 1,028 vehicles were observed entering the campus through Persiaran Universiti 1. It also shows that 1,052 vehicles left the campus via this gate, and 1,043 vehicles passed by using the same entrance.

Table 5 Hourly traffic volume at main road Persiaran Universiti 1

\begin{tabular}{|l|l|l|l|l|l|l|l|l|l|}
\hline $\begin{array}{l}\text { Count } \\
\text { Hour }\end{array}$ & \multicolumn{4}{|l|}{ Wednesday } & \multicolumn{4}{l|}{ Thursday } & \multicolumn{2}{l|}{ Friday } \\
\hline Direction & In & Out & Pass-by & In & Out & $\begin{array}{l}\text { Pass- } \\
\text { by }\end{array}$ & In & Out & $\begin{array}{l}\text { Pass- } \\
\text { by }\end{array}$ \\
\hline $\begin{array}{l}7.00 \mathrm{am}- \\
9.00 \mathrm{am}\end{array}$ & 596 & 453 & 817 & 1028 & 391 & 1020 & 610 & 340 & 1043 \\
\hline $\begin{array}{l}12.00 \mathrm{pm} \\
-2.00 \mathrm{pm}\end{array}$ & 459 & 1052 & 715 & 666 & 635 & 452 & 589 & 389 & 683 \\
\hline $\begin{array}{l}4.00 \mathrm{pm}- \\
6.00 \mathrm{pm}\end{array}$ & 280 & 312 & 472 & 482 & 572 & 567 & 360 & 523 & 549 \\
\hline TOTAL & $\mathbf{1 3 3 5}$ & $\mathbf{1 8 1 7}$ & $\mathbf{2 0 0 4}$ & $\mathbf{2 1 7 6}$ & $\mathbf{1 5 9 8}$ & $\mathbf{2 0 3 9}$ & $\mathbf{1 5 5 9}$ & $\mathbf{1 2 5 2}$ & $\mathbf{2 2 7 5}$ \\
\hline
\end{tabular}

\section{Hours Count of Traffic Flow}

The 18 hours traffic count observation indicates that the highest number of vehicles entered UPM through Gate 3 and the lowest through Gate 1. More vehicles left the campus through Gate 2 compared to Gates 1 and Gate 9. Table 6 presents the cumulative 18 hours count of traffic flow over three weekdays during an active semester. High number of vehicle passing through Persiaran Universiti 1 as the road is servicing other nearby institutions, such as government institutes, secondary schools and residential zones. On average, from a total of 24,854 vehicles recorded over three days, approximately 8,285 vehicles entered the campus daily at an average 1,380 vehicles per hour.

Table 6 Cumulative 18 hours count of traffic flow over three weekdays during an active semester

\begin{tabular}{|c|c|c|c|c|c|c|c|c|c|}
\hline & \multicolumn{2}{|c|}{ Gate 1} & Gate 2 & Gate 3 & \multicolumn{2}{|c|}{ Gate 9} & \multicolumn{3}{|c|}{ Persiaran Universiti 1} \\
\hline & In & Out & Out & In & In & Out & In & Out & Pass-by \\
\hline Car & 3645 & 3721 & 5849 & 5313 & 5257 & 5146 & 3268 & 3122 & 4470 \\
\hline Motorcycle & 1040 & 1533 & 4062 & 2203 & 1903 & 1920 & 1493 & 1373 & 1646 \\
\hline Bus & 281 & 108 & 243 & 49 & 46 & 52 & 293 & 147 & 189 \\
\hline Bicycle & 15 & 23 & 141 & 16 & 16 & 47 & 16 & 25 & 13 \\
\hline TOTAL & 4981 & 6382 & 10295 & 7581 & 7222 & 7165 & 5070 & 4667 & 6318 \\
\hline
\end{tabular}


Zakiah Ponrahono, Noorain Mohd Isa, Ahmad Zaharin Aris, \& Rosta Harun

The Traffic Volume and Level of Service (LOS) of Universiti Putra Malaysia Serdang Campus Main Access

\section{Peak Hour PCU}

The maximum PCU for inbound traffic was 7115.45 at Gate 3 and the maximum PCU for outbound traffic was 9652.7 at Gate 2 (Table7). Meanwhile, 6274.1 PCU passed through Persiaran Universiti 1 during the 18 hours traffic counting. Overall, the highest mode of transport passing through the campus road and entry points was car, followed by motorcycle and bus. This is due to the lack number of public transportation services entering the campus, as well as the location of the campus, which is far from the nearest rail services. The residential area and institutional zones that located nearby also contributes to the daily traffic flow around the campus access road.

Table 7 Cumulative 18 hours count of PCU over three weekdays during an active semester

\begin{tabular}{|c|c|c|c|c|c|c|c|c|c|}
\hline & \multicolumn{2}{|c}{ Gate 1 } & Gate 2 & Gate 3 & \multicolumn{2}{c|}{ Gate 9} & \multicolumn{2}{c|}{ Persiaran Universiti 1 } \\
\cline { 2 - 11 } & In & Out & Out & In & In & Out & In & Out & Pass-by \\
\hline Car & 3645 & 3721 & 5849 & 5313 & 5257 & 5146 & 3268 & 3122 & 4470 \\
\hline Motorcycle & 780 & 1149.75 & 3046.5 & 1652.25 & 1427.25 & 1440 & 1119.75 & 1029.75 & 1234.5 \\
\hline Bus & 843 & 324 & 729 & 147 & 138 & 156 & 879 & 441 & 567 \\
\hline Bicycle & 3 & 4.6 & 28.2 & 3.2 & 3.2 & 9.4 & 3.2 & 5 & 2.6 \\
\hline TOTAL & $\mathbf{5 2 7 1}$ & $\mathbf{5 1 9 9 . 3 5}$ & $\mathbf{9 6 5 2 . 7}$ & $\mathbf{7 1 1 5 . 4 5}$ & $\mathbf{6 8 2 5 . 4 5}$ & $\mathbf{6 7 5 1 . 4}$ & $\mathbf{5 2 6 9 . 9 5}$ & $\mathbf{4 5 9 7 . 7 5}$ & $\mathbf{6 2 7 4 . 1}$ \\
\hline
\end{tabular}

Table 8 summarises the peak hour PCU's at the main access of the UPM Serdang campus during a specific identified time. The maximum vehicles counted for inbound traffic was 1,320 vehicles at Gate 9 from 7.00am-9.00am (Wednesday), whereas the maximum vehicles counted for outbound traffic was 1,397 vehicles at Gate 2 from 4.00pm-6.00pm (Wednesday).

Table 8 Peak hour PCU's at main access

\begin{tabular}{|l|l|c|c|}
\hline Location & Period & Vehicles/2hours & PCU/2hours \\
\hline \multirow{2}{*}{$\begin{array}{l}\text { Gate 1 } \\
\text { Pintu Anjung Putra }\end{array}$} & $\begin{array}{l}\text { Peak Hour for Inbound Traffic } \\
\text { Thursday 7.00am-9.00am }\end{array}$ & 944 & 963.6 \\
\cline { 2 - 4 } & $\begin{array}{l}\text { Peak Hour for Outbound Traffic } \\
\text { Wednesday 4.00pm-6.00pm }\end{array}$ & 1045 & 998.65 \\
\hline $\begin{array}{l}\text { Gate 2 } \\
\text { Pintu Asam Jawa }\end{array}$ & $\begin{array}{l}\text { Peak Hour for Outbound Traffic } \\
\text { Wednesday 4.00pm-6.00pm }\end{array}$ & 1397 & 1326.35 \\
\hline $\begin{array}{l}\text { Gate 3 } \\
\text { Pintu CIMB }\end{array}$ & $\begin{array}{l}\text { Peak Hour for Inbound Traffic } \\
\text { Thursday 7.00am-9.00am }\end{array}$ & 1136 & 1064.75 \\
\hline $\begin{array}{l}\text { Gate 9 } \\
\text { Pintu Tasik Serdang }\end{array}$ & $\begin{array}{l}\text { Peak Hour for Inbound Traffic } \\
\text { Wednesday 7.00am-9.00 am }\end{array}$ & 1320 & 1261.15 \\
\cline { 2 - 4 } $\begin{array}{l}\text { Peak Hour for Outbound Traffic } \\
\text { Friday 4.00pm-6.00pm }\end{array}$ & 1298 & 1223.5 \\
\hline $\begin{array}{l}\text { Main Road } \\
\text { Persiaran Universiti } \\
1\end{array}$ & $\begin{array}{l}\text { Peak Hour for Inbound Traffic } \\
\text { Thursday 7.00am-9.00am }\end{array}$ & $\begin{array}{l}\text { Peak Hour for Outbound Traffic } \\
\text { Wednesday 12.00pm-2.00pm }\end{array}$ & 1028 \\
\hline
\end{tabular}


PLANNING MALAYSIA

Journal of the Malaysia Institute of Planners (2019)

\begin{tabular}{|l|l|c|c|}
\hline Location & Period & Vehicles/2hours & PCU/2hours \\
\hline & $\begin{array}{l}\text { Peak Hour for Pass-by Traffic } \\
\text { Friday 7.00am -9.00am }\end{array}$ & 1043 & 949.95 \\
\hline
\end{tabular}

\section{Level of Service}

The volume/capacity ratio was determined to calculate and the LOS based on peak hour service. Table 9 presents the findings on LOS of the main access to the UPM Serdang campus, which show this to be between $\mathrm{C}$ and $\mathrm{D}$, indicating a stable flow, or stable flow but close to congested road capacity during the peak hours.

Table 9 Level of service of the main access to the UPM Serdang Campus

\begin{tabular}{|c|c|c|c|c|c|c|c|}
\hline Location & Time & $\begin{array}{c}\text { Peak Hour } \\
\text { Traffic in } \\
\text { PCU/2hours }\end{array}$ & \begin{tabular}{|c|} 
Total \\
Width of \\
road $(\mathrm{m})$ \\
\end{tabular} & $\begin{array}{l}\text { No. of } \\
\text { Lane }\end{array}$ & $\begin{array}{l}\text { Design } \\
\text { Service } \\
\text { Volume } \\
\end{array}$ & $\begin{array}{l}\mathrm{V}-\mathrm{C} \\
\text { ratio }\end{array}$ & $\begin{array}{l}\text { Level of } \\
\text { Service } \\
(\mathrm{LOS}) \\
\end{array}$ \\
\hline \multirow{2}{*}{$\begin{array}{l}\text { Gate 1 } \\
\text { Pintu } \\
\text { Anjung } \\
\text { Putra }\end{array}$} & $\begin{array}{l}\text { Peak Hour for } \\
\text { Inbound } \\
\text { Traffic } \\
\text { Thursday } \\
\text { 7.00am- } \\
9.00 \mathrm{am} \\
\end{array}$ & 963.6 & \multirow{2}{*}{15.56} & 1 & 2000 & 0.48 & $\mathrm{C}$ \\
\hline & $\begin{array}{l}\text { Peak Hour for } \\
\text { Outbound } \\
\text { Traffic } \\
\text { Wednesday } \\
4.00 \mathrm{pm}- \\
6.00 \mathrm{pm} \\
\end{array}$ & 998.65 & & 1 & 2000 & 0.50 & $\mathrm{C}$ \\
\hline $\begin{array}{l}\text { Gate } 2 \\
\text { Pintu } \\
\text { Asam Jawa }\end{array}$ & $\begin{array}{l}\text { Peak Hour for } \\
\text { Outbound } \\
\text { Traffic } \\
\text { Wednesday } \\
4.00 \mathrm{pm}- \\
6.00 \mathrm{pm} \\
\end{array}$ & 1326.35 & 7.3 & 1 & 2000 & 0.66 & $\mathrm{D}$ \\
\hline $\begin{array}{l}\text { Gate } 3 \\
\text { Pintu } \\
\text { CIMB }\end{array}$ & $\begin{array}{l}\text { Peak Hour for } \\
\text { Inbound } \\
\text { Traffic } \\
\text { Thursday } \\
\text { 7.00am- } \\
\text { 9.00am }\end{array}$ & 1064.75 & 18.2 & 1 & 2000 & 0.53 & $\mathrm{C}$ \\
\hline \multirow[t]{2}{*}{$\begin{array}{l}\text { Gate } 9 \\
\text { Pintu Tasik } \\
\text { Serdang }\end{array}$} & $\begin{array}{l}\text { Peak Hour for } \\
\text { Inbound } \\
\text { Traffic } \\
\text { Wednesday } \\
\text { 7.00am- } \\
9.00 \mathrm{am} \\
\end{array}$ & 1261.15 & \multirow[t]{2}{*}{15.1} & 1 & 2000 & 0.63 & $\mathrm{D}$ \\
\hline & $\begin{array}{l}\text { Peak Hour for } \\
\text { Outbound } \\
\text { Traffic Friday }\end{array}$ & 1223.5 & & 1 & 2000 & 0.61 & $\mathrm{D}$ \\
\hline
\end{tabular}


Zakiah Ponrahono, Noorain Mohd Isa, Ahmad Zaharin Aris, \& Rosta Harun

The Traffic Volume and Level of Service (LOS) of Universiti Putra Malaysia Serdang Campus Main Access

\begin{tabular}{|c|c|c|c|c|c|c|c|}
\hline Location & Time & $\begin{array}{c}\text { Peak Hour } \\
\text { Traffic in } \\
\text { PCU/2hours }\end{array}$ & $\begin{array}{c}\text { Total } \\
\text { Width of } \\
\text { road (m) }\end{array}$ & $\begin{array}{l}\text { No. of } \\
\text { Lane }\end{array}$ & $\begin{array}{l}\text { Design } \\
\text { Service } \\
\text { Volume }\end{array}$ & $\begin{array}{l}\mathrm{V}-\mathrm{C} \\
\text { ratio }\end{array}$ & $\begin{array}{l}\text { Level of } \\
\text { Service } \\
\text { (LOS) }\end{array}$ \\
\hline & $\begin{array}{l}4.00 \mathrm{pm}^{-} \\
6.00 \mathrm{pm} \\
\end{array}$ & & & & & & \\
\hline \multirow{3}{*}{$\begin{array}{l}\text { Main Road } \\
\text { Persiaran } \\
\text { Universiti } \\
1\end{array}$} & $\begin{array}{l}\text { Peak Hour for } \\
\text { Inbound } \\
\text { Traffic } \\
\text { Thursday } \\
\text { 7.00am- } \\
9.00 \mathrm{am}\end{array}$ & 969.5 & \multirow{3}{*}{25} & 1 & 2000 & 0.48 & $\mathrm{C}$ \\
\hline & $\begin{array}{l}\text { Peak Hour for } \\
\text { Outbound } \\
\text { Traffic } \\
\text { Wednesday } \\
12.00 \mathrm{pm}- \\
2.00 \mathrm{pm}\end{array}$ & 1046 & & 1 & 2000 & 0.52 & $\mathrm{C}$ \\
\hline & $\begin{array}{l}\text { Peak Hour for } \\
\text { Pass-by } \\
\text { Traffic Friday } \\
\text { 7.00am- } \\
9.00 \mathrm{am}\end{array}$ & 949.95 & & 1 & 2000 & 0.47 & $\mathrm{C}$ \\
\hline
\end{tabular}

Table 10 summarises the maximum total of inbound and outbound traffic, as well as pass-by traffic volumes at the main access of UPM Serdang campus over 18 hours of traffic count. The maximum total inbound of traffic volume at the main access of the UPM Serdang campus was 7,581 vehicles at Gate 3 with B LOS of hourly road service. On the other hand, the maximum total outbound of traffic volume over 18 hours of traffic count at the main access of UPM Serdang campus was 10,295 vehicles at Gate 2 with B LOS of hourly road capacity. Meanwhile, the total pass-by traffic volume at Persiaran Universiti 1 was 6,318 vehicles with A LOS of hourly road capacity.

Table 10 Maximum of inbound, outbound and pass-by traffic volume at the main access of UPM Serdang Campus

\begin{tabular}{lccccc}
\hline $\begin{array}{c}\text { Name of the } \\
\text { Access }\end{array}$ & $\begin{array}{c}\mathbf{1 8} \text { - } \\
\text { hour } \\
\text { count }\end{array}$ & $\begin{array}{c}\text { Maximum Traffic } \\
\text { Volume }\end{array}$ & $\begin{array}{c}\text { Road Capacity } \\
\text { (PCU/hr) }\end{array}$ & $\begin{array}{c}\text { V-C } \\
\text { ratio }\end{array}$ & $\begin{array}{c}\text { Level } \\
\text { of } \\
\text { ofvice } \\
\text { (LOS) }\end{array}$ \\
\hline $\begin{array}{l}\text { Total inbound } \\
\text { at Gate 3 }\end{array}$ & $\mathbf{7 5 8 1}$ & $\begin{array}{c}\mathbf{1 1 3 6} \\
\text { (Thursday 7.00 am } \\
\text { Pintu CIMB }\end{array}$ & $\begin{array}{c}7115.45 / 2000 \\
=3.56\end{array}$ & 0.20 & $\mathrm{~B}$ \\
\hline $\begin{array}{l}\text { Total } \\
\text { outbound } \\
\text { traffic at Gate }\end{array}$ & $\mathbf{1 0 2 9 5}$ & $\begin{array}{c}\mathbf{1 3 9 7} \\
\text { (Wednesday } 4.00 \\
\text { pm - 6.00 pm) }\end{array}$ & $\begin{array}{c}9652.7 / 2000 \\
=4.83\end{array}$ & 0.27 & $\mathrm{~B}$ \\
$\begin{array}{l}\text { Jawn Assam } \\
\text { Jawa }\end{array}$ & & & & & \\
\hline
\end{tabular}


PLANNING MALAYSIA

Journal of the Malaysia Institute of Planners (2019)

\begin{tabular}{lccccc}
\hline $\begin{array}{c}\text { Name of the } \\
\text { Access }\end{array}$ & $\begin{array}{c}\mathbf{1 8}- \\
\text { hour } \\
\text { count }\end{array}$ & $\begin{array}{c}\text { Maximum Traffic } \\
\text { Volume }\end{array}$ & $\begin{array}{c}\text { Road Capacity } \\
\text { (PCU/hr) }\end{array}$ & $\begin{array}{c}\text { V-C } \\
\text { ratio }\end{array}$ & $\begin{array}{c}\text { Level } \\
\text { of } \\
\text { Service } \\
\text { (LOS) }\end{array}$ \\
\hline $\begin{array}{l}\text { Pass-by traffic } \\
\text { at Persiaran }\end{array}$ & $\mathbf{6 3 1 8}$ & $\begin{array}{c}\mathbf{1 0 4 3} \\
\text { (Friday 7.00 am }-\end{array}$ & $\begin{array}{c}6274.1 / 2000 \\
=3.14\end{array}$ & 0.17 & $\mathrm{~A}$ \\
\hline
\end{tabular}

These traffic flow findings of the UPM Serdang campus may differ from other university campuses, particularly in Malaysia, according to the geographical setting of the campus, road and traffic system design, total campus population, and other factors, such as the location of nearby public transportation services and in-campus residential policies. The size of the campus, building layout and master plan also significantly contribute to the traffic flow and levels of service of the road. For instance, the traffic condition in International Islamic University Malaysia (Abdul Azeez, 2011) showed similar findings with UPM Serdang's traffic flow. This similarity may be caused by a similar population range and the location of the public transportation system, e.g, rail services that are far from the campus. Hence, other factors, such as the different traffic movement systems in both universities, are not significantly contributors. Meanwhile, other universities such as the University of Malaya, Universiti Kebangsaan Malaysia, etc. may have different traffic movements, depending on these contributing factors.

\section{CONCLUSION}

This study was conducted to analyse the traffic characteristics of the UPM Serdang campus. The following main conclusions are drawn from the work:

1. As per the data collected from the traffic volume study fover 18 hours of counting, it was found that the maximum number of vehicles arriving at the campus was 7,581 entering the campus through Gate 3 Pintu CIMB and 10,295 vehicles leaving the campus through Gate 2, Pintu Assam Jawa.

2. The minimum traffic (over 18 hours) observed was 4,981 inbound campus traffic through Gate 1 Pintu Anjung Putra, and 4,667 vehicles leaving the campus using the main road, Persiaran Universiti 1.

3. The traffic composition of the vehicles arriving and leaving the campus comprised cars at 50-70 percent, motorcycles at 20-40 percent, buses at 5-10 percent and bicycles at 1-2 percent, from all main accesses.

4. The peak hour of the traffic entering the campus was found to be between 7:00am-9:00am on Thursday at Gate 1 (944 vehicles), Gate 3 (1,397 vehicles) 
Zakiah Ponrahono, Noorain Mohd Isa, Ahmad Zaharin Aris, \& Rosta Harun

The Traffic Volume and Level of Service (LOS) of Universiti Putra Malaysia Serdang Campus Main Access

and Persiaran Universiti 1 (1,028 vehicles), and on Wednesday at Gate $9(1,320$ vehicles).

5. The peak hour of traffic leaving the campus was found to be between $4: 00 \mathrm{pm}-$ 6:00pm on Wednesday at Gate 1 (1,045 vehicles), Gate 3 (1,397 vehicles) and Persiaran Universiti 1 (1,052 vehicles), and on Friday at Gate 9 (1,298 vehicles).

6. The level of service as calculated for all main access of the UPM Serdang campus was found to be between C- D level of service against all the peak hour traffic.

7. More vehicles entered the campus through Gate 3 (7,851 vehicles) and more vehicles leave the campus through Gate 2 with 10,295 vehicles observed over 18 hours.

8. The comparative study between different university campuses is suggested for future research to identify common on-campus transportation system issues and develop sustainable transportation campus indices.

\section{ACKNOWLEDGEMENTS}

This research was fully supported by the UPM Putra Grant - Current Issue 9300437 (UPM RMC).

\section{REFERENCES}

Abdul Azeez Kadar Hamsa (2011). Analysis of Traffic Flow Characteristics in a University Setting. In International Transport Research Conference - A Road Map for Safer Mobility. April 12-13, 2011, Penang, Malaysia.

Abd-Razak, M. Z., Mustafa, N. K. F., Che-Ani, A. I., Abdullah, N. A. G., \& Mohd-Nor, M. F. I. (2011). Campus sustainability: Student's perception on campus physical development planning in Malaysia. Procedia Engineering, 20, 230-237.

Aoun, A., Abou-Zeid, M., Kaysi, I., \& Myntti, C. (2013). Reducing parking demand and traffic congestion at the American University of Beirut. Transport Policy, 25, $52-60$.

Azzali, S., \& Abdel Sabour, E. (2018). A framework for improving sustainable mobility in higher education campuses: The case study of Qatar University. Case Studies on Transport Policy, 6(4), 603-612.

Curtis, C., \& Scheurer, J. (2010). Planning for sustainable accessibility: Developing tools to aid discussion and decision-making. Progress in Planning, 74(2), 53-106.

Dontu, A. I., Maftei, A., Barsanescu, P. D., Sachelarie, A., \& Budeanu, B. (2016). Method of preventing unwanted traffic in the "tudor Vladimirescu" University Campus. IOP Conference Series: Materials Science and Engineering, 147(1), 012111.

Gopikrishna, J., \& Shanmugapriyan, V. (2015). Critical study on road inventory and traffic circulation for ensuring road safety in CEG campus. Indian Journal of Science and Technology, 8(32), 6-9. 
Lundberg, B., \& Weber, J. (2014). Non-motorized transport and university populations: An analysis of connectivity and network perceptions. Journal of Transport Geography, 39, 165-178.

Norzalwi, N., \& Ismail, A. (2011). Public approach towards sustainable transportation in UKM's campus. Australian Journal of Basic and Applied Sciences, 5(5), 13321337.

Public Works Department Malaysia (1986). Arahan teknik (Jalan) 8/86: A guide on geometric design of roads.

Singh, B., \& Goyal, T. (2015). Study of traffic volume and level of service of Panjab University, Chandigarh. International Journal of Engineering Research and Applications, 5(7), 9-14.

Soria-Lara, J. A., Marquet, O., \& Miralles-Guasch, C. (2017). The influence of location, socioeconomics, and behaviour on travel-demand by car in metropolitan university campuses. Transportation Research Part D: Transport and Environment, 53, 149-160

Received: $12^{\text {th }}$ January 2019. Accepted: $2^{\text {nd }}$ August 2019 